\title{
Armine Kotin Mortimer, Sollers's «Le Secret», Espionage and Autofiction
}

\section{Elisa Bricco}

\section{Q OpenEdition}

1 Journals

\section{Edizione digitale}

URL: https://journals.openedition.org/studifrancesi/41276

DOI: 10.4000/studifrancesi.41276

ISSN: 2421-5856

\section{Editore}

Rosenberg \& Sellier

\section{Edizione cartacea}

Data di pubblicazione: 1 juillet 2004

Paginazione: 224

ISSN: 0039-2944

\section{Notizia bibliografica digitale}

Elisa Bricco, «Armine Kotin Mortimer, Sollers's «Le Secret», Espionage and Autofiction», Studi Francesi [Online], 142 (XLVIII | I) | 2004, online dal 30 novembre 2015, consultato il 09 septembre 2021. URL: http://journals.openedition.org/studifrancesi/41276; DOI: https://doi.org/10.4000/studifrancesi. 41276

Questo documento è stato generato automaticamente il 9 septembre 2021.

\section{(c)}

Studi Francesi è distribuita con Licenza Creative Commons Attribuzione - Non commerciale - Non opere derivate 4.0 Internazionale. 


\title{
Armine Kotin Mortimer, Sollers's «Le Secret», Espionage and Autofiction
}

\author{
Elisa Bricco
}

\section{NOTIZIA}

ARMINE KOTIN MORTIMER, Sollers's «Le Secret», Espionage and Autofiction, «L'Esprit Créateur», 2002, XLII, 4, pp.35-44.

1 Il romanzo Le Secret di Philippe Sollers è particolare perché mette in scena il racconto autofinzionale di un lutto, utilizzando la struttura del romanzo giallo. Seguendo le avventure della spia protagonista, alter-ego dello scrittore, il lettore è portato alla scoperta di un avvenimento molto personale della storia di Sollers, la morte della madre. Riordinando i tasselli che compongono il romanzo, l'A. riesce a ricondurre ogni elemento della storia all'io-scrittore, e mette in luce quanto il lutto sia fondamentale e costitutivo nell'economia della narrazione. Inoltre, A.KOTIN MORTIMER rileva gli elementi che le consentono di stabilire che si tratta di una autofiction, in cui lo scrittore mette in scena se stesso, attraverso avvenimenti della sua vita personale, suoi profondi convincimenti di ordine ontologico e esistenziale, fino a diventare egli stesso la spiaprotagonista. 